2

$\mathrm{DOE} / \mathrm{MC} / 11076--2912$

DE91 002004

\title{
Investigation of the $\mathrm{ROPE}^{\circledR}$ Process \\ Performance on Sunnyside Tar Sand
}

Topical Report

C.Y. Cha

L.A. Johnson, Jr.

F.D. Guffey

July 1990

Work Performed Under Cooperative Agreement No.: DE-FC21-86MC11076

For

U.S. Department of Energy

Office of Fossil Energy

Morgantown Energy Technology Center

Morgantown, West Virginia

By

Western Research Institu: :

Laramie, Wyoming 


\section{DISCLAIMER}

This report was prepared as an account of work sponsored by an agency of the United States Government. Neither the United States Government nor any agency thereof, nor any of their employees makes any warranty, express of implied, or assumes any legal liability or responsibility for the accuracy, completeness or usefulness of any information, apparatus, product, or process disclosed, or represents that its use would not infringe privately owned rights. Reference herein to any specific commercial product, process, or service by trade name, trademark, manufacturer, or otherwise, does not necessarily constitute or imply its endorsement, recommendation, or favoring 'sy the United States Government or any agency thereof. The views and opinions of authors expressed herein do not necessarily state or reflect those of the United States Government or any agency thereof.

This report has been reproduced directly from the best available copy.

Available to DOE and DOE contractors from the Office of Scientific and Technical Information, P.O. Box 62, Oak Ridge, TN 37831; prices available from (615)576-8401, FTS 626-8401.

Available to the public from the National Technical Information Service, U.S. Department of Commerce, 5285 Port Royal Rd., Springfield, VA 22161. 


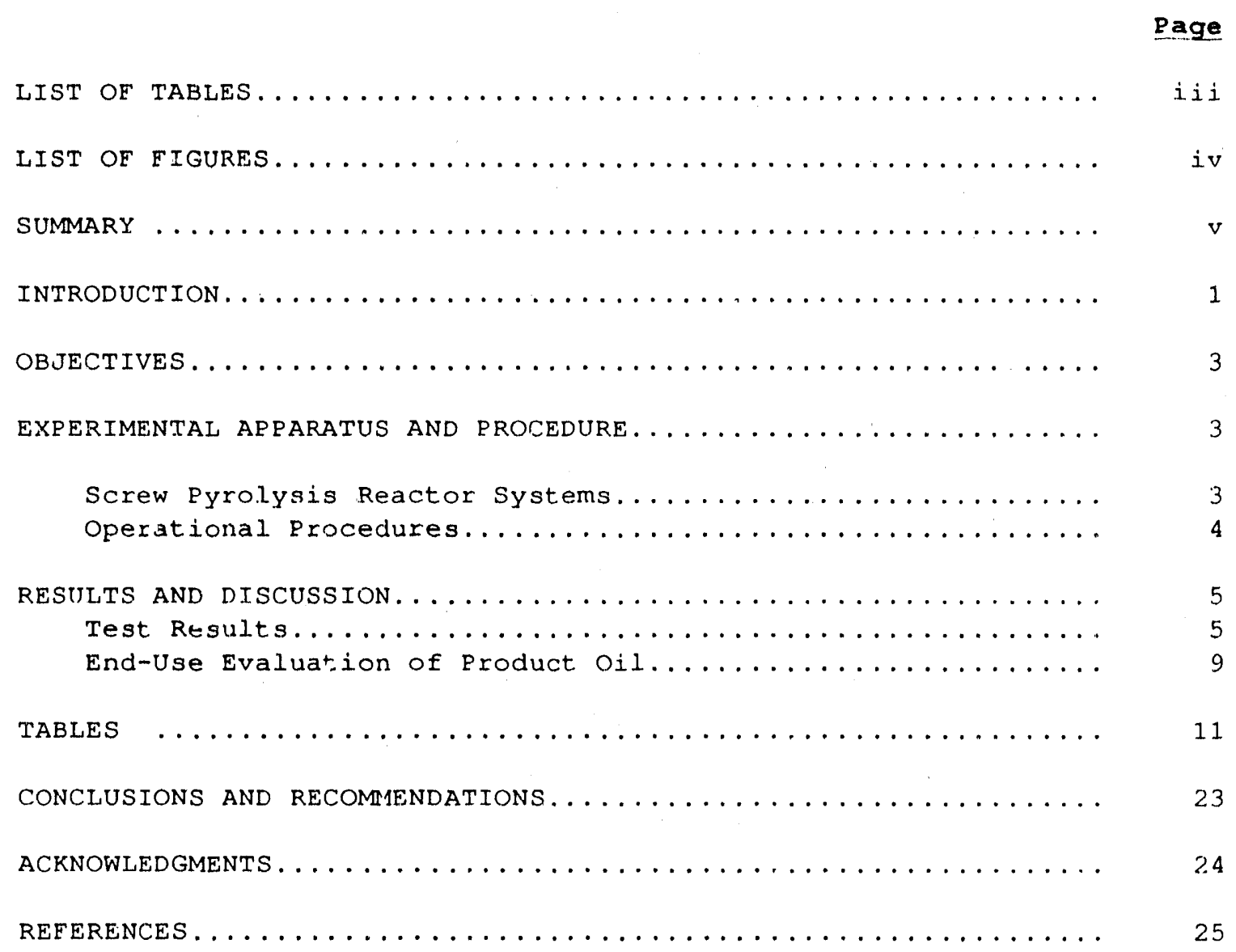


1. Test Conditions for Sunnyside RUPE ${ }^{(\mathcal{C})}$ Test............. 10

2. Bitumen Content of $\operatorname{Tar}$ Sand Feeds.................. 10

3. Product Distribution and Elemental Composition

Determined by Fisher Assay Analysis of Sunnyside

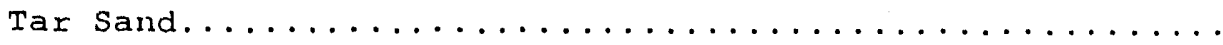

4. Gas Composition Determination by Mass Balance Fisher Assay Analysis of Sunnyside Tar sand...............

5. Properties of Sunnyside Bitumen.................. 13

6. Overall Material Balances for the 24-Hour Tests........ 14

7. Calculated Profuct Yields for the 24 -Hour Tests........ 15

8. Composition of Product Gas for the 24-Hour Tests,

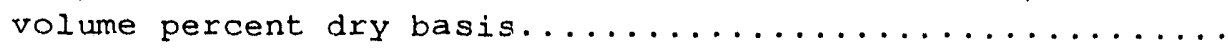

9. Measured Product Yields for the 105-Hour Test,

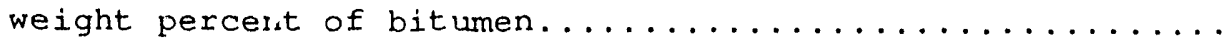

10. Calculated Oil Yield for the 105-Hour Test,

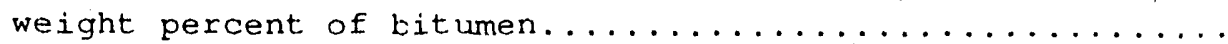

11. Overall Material Balance for the 105-Hour Test........

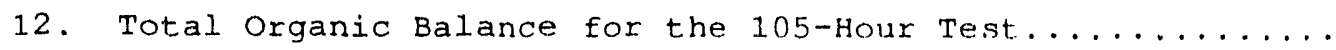

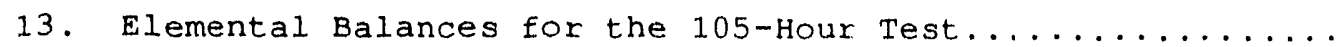

14. OiI Compositions and Properties for the 105-Hour Tert....

15. Composition of Product Gas for the 105-Hour Test,

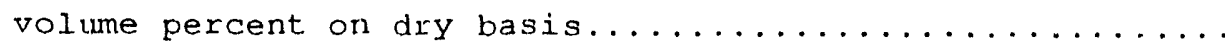

16. Comparison of Hydrocarbon-Group Types Identified in the IBP-350 $\mathrm{F}$ Distillate Fraction from the 105-Hour Test

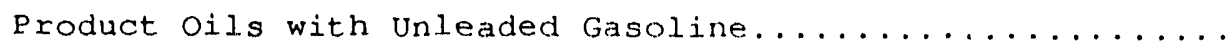

17. Comparison of Hydrocarbon-Group Types Identified in the 350-700 $\mathrm{F}$. Distillate Fraction from the 105-Hour Test. Product Oils with Prototype High-Density Fuel ar. I Diesel.

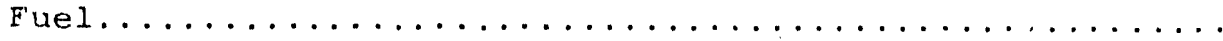


LIST OF FIGURES

$\begin{array}{ll}\text { Figure } & \text { Page }\end{array}$

1. Two-Inch Screw Pyrolysis Reactor system.............. 2

2. Residual Carbon in Spent Sand for Sunnyside

Tar Sand Tests .......................... 7

3. Product Distribution for Sunnyside Tar Sand Tests....... 8 


\section{SUMMARY}

Western Research Instjtute (WPT) is developing the Recycle Oil. Pyrolysis and Extraction (ROEE ${ }^{(9)}$ process. Results to date indicate that this process could assist existing surface recovery process economics by producing higher yields of feedstocks from tar sand for the production of unleaded gasoline and advanced aviation turbine fuel. The ROPE $^{(\mathcal{C})}$ process also will assist in situ recovery process economics by producing a diluent to decrease the pour point and viscosity of produced bitumen for pipeline transportation and by producing a solvent for solvent extraction processes.

The main objectives of this research were to determine the optimum pyrolysis temperature for sunnyside tar sand and to verify the operability and efficiency of the ROPE process at steady-state conditions for production of feedstock materials. The experiments were conducted in the 2 -inch screw pyrolysis reactor (SRR) developed by WRI.

Four 24-hour tests and one 105-hour test were performed in the 2inch SRR using sunnyside tar sand. The 24-hour tests were designed to predict the optimum pyrolysis temperature for oil yield. The 105-hour test was conducted to confirm the optimum pyrolysis temperature with sufficient operating time to reach strady-state conditions with respect to product compositions.

The following conclusions can be drawn from the sunnyside tar sand 2-inch SRR tests:

- Sunnyside tar sand can be processed without any major operational difficulty by the ROPE $^{(\mathcal{C}}$ process.

- Oil yields greater than Fischer assay were obtained during the 2inch SPR tests. Oil yield greater than 80 wt \& of the bitumen was obtained from the 105-hour test. The variation in oil yield was small in the temperature range of 600 to $700^{\circ} \mathrm{F}\left(316\right.$ to $\left.371^{\circ} \mathrm{C}\right)$, which provides a wide operating range. The pyrolysis temperature of the sunnyside tar. sand was approximately $100^{\circ} \mathrm{F}\left(38^{\circ} \mathrm{C}\right)$ lower than the optimum pyrolysis temperature for Asphalt Ridge tar sand.

- The ratio of heavy oil to light product oil is strongly dependent upon the pyrolysis temperature and increases with a decrease in the reaction temperature. The gas yield increases with the increase in pyrolysis temperature but the residual carbon in the spent sand decreases with the increase in pyrolysis temperature, reaches minimum at $675^{\circ} \mathrm{F}\left(357^{\circ} \mathrm{C}\right)$, and then increases with further increase in the pyrolysis temperature.

- ROPE $^{(}$process product oils from sunnyside tar sand have market application as blending stocks for the production of diesel flels, but they are not suited for the production of unleaded gasoline or highdensity aviation turbine 


\section{INTRODUCTION}

Major ohstarles to the commerrialization of tar sand are the high costs associated with mining and processing, the upgrading of the raw tar sand oil, and refining the upgraded tar sand oil to produce salable products. In order to encourage tar sand commercialization with much reduced financial risks, new processing technologies need to be developed. The overall objective of the western Research Institute has been to develop a new process that produces (1) oil yields greater than other existing pyrolysis processes, (2) transportation and aviation fuel feedstocks, (3) a diluent to decrease the pour point and viscosity of bitumen for pipelining, and (4) a solvent for extraction processes.

WRI has developed the Recycle Oil pyrolysis and Extraction (ROPE ${ }^{(C)}$ ) process. The process, in its entirety, consists of four major steps: (1) preheating and extracting the hydrocarbonaceous material with product oil, (2) retcrting the extracted material at a low temperature $\left(\leq 750^{\circ} \mathrm{F} / 400^{\circ} \mathrm{C}\right)$ with recycle product oil, (3) completing the pyrolysis of residue at a higher temperature $\left(>750^{\circ} \mathrm{F} / 400^{\circ} \mathrm{C}\right)$ in the absence of product oil recycling, and (4) combusting the solid residue and pyrolysis gas to produce the required process heat.

WRI constructed and operated two reactor systems to test the ROPE ${ }^{(C)}$ process. The smaller system $(2-4 \mathrm{~kg} / \mathrm{hr}$ solids-throughput capacity) is a 2-inch diameter screw pyrolysis reactor (SPR), which is used to conduct. a large number of sinort-duration tests to determine optimum operating conditions (Figure 1). The larger system $(20-40 \mathrm{~kg} / \mathrm{hr}$ solids-throughput capacity) is a 6-inch diameter SPR, which is used to conduct longer duration tests to confirm the optimum conditions determined in the 2inch SPR tests.

Previously, tests were conducted in the 2-inch SPR and 6-inch SPR using Asphalt Ridge, Utah, and Arroyo Grande, California, tar sand to determine the effects of pyrolysis temperature and residence time on the oil yield and product distribution. Also, these tests produced samples for the evaluation of product oil characteristios (Cha et al. 1987, 1988; Vaughn et al. 1990). The product oil samples were analyzed to determine the distribution of hydrocarbon types and to relate this distribution to that found in other fuel types.

Results from these tests suggest that the ROPE ${ }^{C}$ process will assist existing surface and in situ recovery process economics in the following ways: (1) by producing a diluent to decrease the pour point and viscosity of produced bitumen for pipeline transportation, (2) by producing a solvent for solvent extraction processfs, (3) and by producing feedstocks for the production of unleaded gasoline and advanced aviation turbine fuel. 


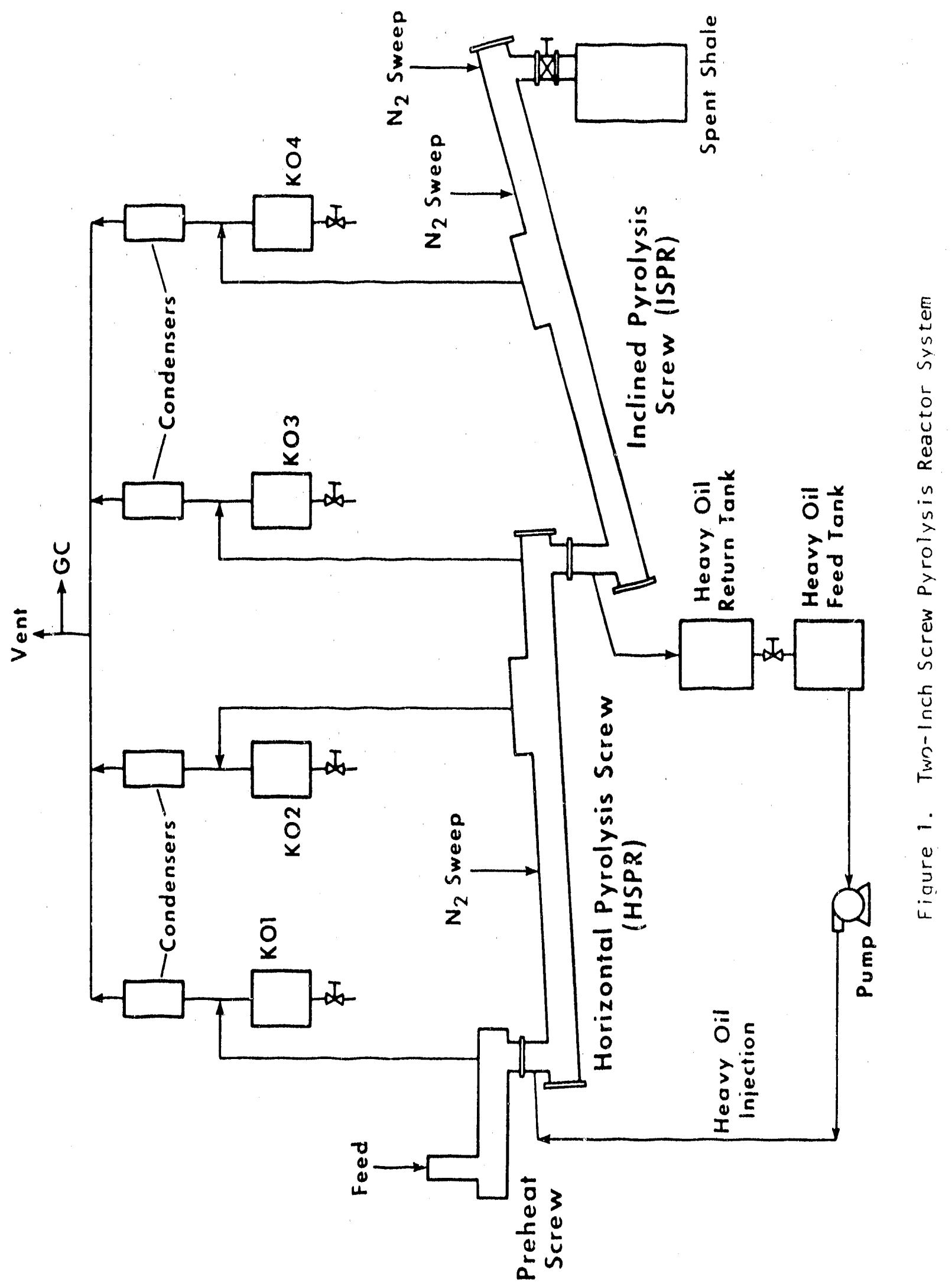




\section{OBJECTIVES}

The ohjectives of this project were to determine the opt imum Fyrolysis temperature for the ROPE (O) process and to confirm that temperature at steady-state conditions by conducting tests in the 2-inch SPR. In addition, the characteristics of the product oil were determined.

EXPERIMENTAL APPARATUS AND RROCEDURE

\section{Screw Pyrolysis Reactor: Systems}

The ROPE ${ }^{(\mathcal{O}}$ process has heen designed to facilitate both laboratory e perimentation and commercial application. The design for the 2-inch system is shown in Figure 1. The design of the 6-inch SPR is similar to that for the 2-inch system. The systems consist of the following major subsystems:

- Feed system including a preheating screw reactor

- Pyrolysis screw reactor

- Drying (inclined pyrolysis) screw reactor

- Heavy product oil recycle system

- Reflux condensers and knockcuts

- Sweep gas injection system

- Spent solids tank

The initial preheat screw conveyor controls the feed rate and temperature of $t a r$ sand into the reactor system. Batches of tar sand are weighed, sampled, and fed into the feed hopper. The feed rate is calculated by measuring the time required to empty the feed hopper, and the feed rate is controlled by adjusting the feed screw rotation speed. Heat, if required, is provided by electric heaters placed around the screw conveyor to preheat the feed. product oil may also be added in this screw to initiate bitumen extraction from the tar sand. This screw reactor is sealed from the pyrolysis screw reactor by the inventory of product oil and tar sand that is in the system.

The slurry of sand, bitumen, and product oil then enters the pyrolysis screw reactor. Heavy oil is recycled coculrently to the incoming slurry, and pyrolysis of the total mixture occurs. The residence time of the slurry mixture is controlled by the feed rate and the speed of the screw conveyor in the pyrolysis reactor. Flect.rin heaters also surround the pyrolysis screw reactor, and the conversion ol recycle heavy oil is controlled by adjusting the reactor temperature. The relative rates of recycle heavy oij, conversion and hydrocarbon extraction are monitored by measuring the liquid levels in the product oil and heavy oil tanks.

Residual hydrocarbons on the sand, that escape extraction and evaporation in the pyrolysis screw reactor, are pyrolyzed at. a higher temperature in the drying screw reactor. A level of heavy oil is maintained in the lowest section of the drying screw to provide a seal between the two pyrolysis systems. Electric heaters surrounding the 
drying screw reactor heat the extracted sand to marimum temperatures of $800-975^{\circ} \mathrm{F} \quad\left(427-524^{\circ} \mathrm{C}\right)$. This final pyrolysis temperature is controlled to produce a dry material containing only residual carhon and mineral matter. To minimize residual hydrocarbon pyrolysis at high temperatures in the drying screw reactor, the tar sand feed rate is adjusted t.o maximize extraction of hydrocarbons jn the preheating and pyrolysis reactors.

Separate condensers and knockouts (KO1, KO2, KO3, and KO4) collect product oil from each of the three screw reactors. Condensed product oil from each knockout is measured separately to cietermine the effectiveness of the pyrolysis process. After these measuro! lents are made, the product oils from the pyrolysis screw reactor (KO2. and KO3) are combined and retained. The product from KO4 is retained for use as product oil injection into the pyrolysis screw reactor. condensed liquids from the preheating screw reactor (KO1) are also collected and retained separately.

Nitrogen is used to sweep distilled products from each of the pyrolysis and drying screw reactors. The nitrogen sweep rate and product gas concentration are measured to calculate the product gas production rate using a nitrogen balance. The outlet gas flow rate is also measured every hour using a bubble tube.

Spent sand is collected in a tank at the end of the drying screw reactor. The material is sampled periodically to determine if any changes are occurxing in the spent sand properties. Each sample is weighed to determine the spent sand production rate.

\section{Operational Procedures}

Four 24-hour tests, test numbers 1 through 4, and one 105-hour test, number 5, were performed in the 2-inch SPR using sunnyside tar sand. The 24-hour tests were started using SAE50 weight motor oil as the initial recycle oil (Table 1). The SAE50 weight was used to provide a commonality point between the initial tests and has been used in other test series to provide the same condition. The effect of using SAE50 weight and its 1 ifetime in the reactor system are presently being studied. The 105-hour test was initiated with a mixture of KO2, KO3, and KO4 product oil produced during the 3rd and 4th 24-hour tests (Table 1). The KO2 product oil produced during the initial 33 hours of the 105-hour test was retained. The $k 04$ product $c i l$ and heavy oil produced for the initial 33 hours were recycled for the final 72 hour steadystate period of the 105-hour test. The 24-hour test conditions were used to determine the optimum pyrolysis temperature and to produce an initial recycle oil for the 105-hour test.

Based on the optimum pyrolysis temperature trom the initial. four tests, the 105-hour test was designed to produce oil at steady-state conditions. This long-term test was operated in two phases, an initial phase with a pyrolysis temperature of $600^{\circ} \mathrm{F}\left(316^{\circ} \mathrm{C}\right)$ to produce a larger amount of heavy recycle oil and a second phase at $650^{\circ} \mathrm{F}\left(343^{\circ} \mathrm{C}\right)$ to provide products in a steady-rtate environment. The roavy oil was not recycled in the initial phase, anc the product oil produced from 
previcus tests was continuously injected. The initial 33-hour and final 72-hour phases were conducted without any break in operations. This test and all other tests were conducted with minimal cperational problems.

For this reactor system operated at the set rpm value for each screw, the residence time for the preheat (feed), the pyrolysis, and the drying screws are 10,20 , and $30 \mathrm{~min}$, respectively. These residence times were measured for each screw segment by using dry sand as feed and correlating screw rpm with the weight of the produced sand.

The bitumen content of the raw tar sand and the spent sand were determined by soxhlet extraction using toluene and pyridine as the solvents. The extraction was performed by first extracting the tar sand with toluene for 16 hours. Then, the remaining bitumen was extracted with pyridine for an alditional 16 hours. The solvent was removed from the extracts by rotary evaporation. The material extracted with both solvents was combined into a single sample prior to analysis. The residual carbon remaining on the sand after extraction and the residual carbon remaining on the spent sand were determined by weight loss from combustion at $400^{\circ} \mathrm{C}\left(750^{\circ} \mathrm{F}\right)$.

\section{RESULTS ALD DISCUSSION}

\section{Test Results}

The tar sand used for these tests was prepared by crushing and screening large samples from a quarry at sunnyside, Utah. A composite sample of the feed material for each test was prepared by taking approximately $10 \mathrm{~g}$ of the material during every charge to the feed hopper. The bitumen content fur the composite material for each test was determined by solvent extraction with residual carbon determined hy combustion of the extracted and. The bitumen content ranged from 8.9 to 10.9 wt of with a total organic content of 9.5 to 11.6 wt 8 ('Table 2). A mass balance Fisher assay of the Sunnyside tar sand was performed to provide a base line for comparison of the ROPE ${ }^{0}$ process (Tables 3 and 4).

The bitumen in the sunnyside tar sand is a heavy, viscous hydrocarbon with a specific gravity of 0.997 and an in-place viscosity exceeding $1.6 \times 10^{8} \mathrm{cP}$ (Table 5). The bitumen is a near solid at ambient temperature with over $68 \%$ of the material having a boiling point greater than $1000^{\circ} \mathrm{F}\left(538^{\circ} \mathrm{C}\right)$. Sulfur content is only 0.46 wt $\%$ with a hydrogen-to-carbon ratio of 1.62 .

For the four 24-hour tests, the overall material balances varied from 96.1 to 105.2 percent closure and are assumed acceptahle for the determination of the optimum pyrolysis temperature (Table 6). calculated product yields from the four 24-hour tests are summarized in Table 7. The determination of the optimum temperature was based on the residual carbon content in the spent sand (Figure 2) and the product yields. Based on the higher oil and the relatively low residual carbon content, the selected optimum pyrolysis temperature is $650^{\circ} \mathrm{F}\left(343^{\circ} \mathrm{C}\right)$. 
Product gas yields and gas compositions for the four tests are presented in Tables 7 and 8, respectively. Generally, a significantly higher weight percert of total organics was produced as gas as the pyrolysis temperature was increased. The methane and higher hydrocarbon corcentrations were higher for the $725^{\circ} \mathrm{F}\left(385^{\circ} \mathrm{C}\right)$ test, indicating that more cracking occurred. The higher rate of cracking is also evident by the higher residual carbon content.

The measured oil yield for the entire 105-hour test of 82.3 wt. \% (Table 9) is in excellent agrement with the 82.4 wt' oil yield for the $650^{\circ} \mathrm{F}\left(343^{\circ} \mathrm{C}\right) 24$-hour test. The calculated oil yield of 81.2 wt $\%$ for this test (Table 10) also supports the measured oil yield and is 124 of the Fisher assay oil yield. The measured residual carbon content for the individual phases (the $600^{\circ} \mathrm{F}\left(316^{\circ} \mathrm{C}\right)$, and the uppermost $650^{\circ} \mathrm{F}\left(343^{\circ} \mathrm{C}\right)$ points on Figure 2) are also in agreement with the results of the $24-$ hour test and support the validity of the 105-hour test data. The product distribution for the individual test phases when compared with the distributions for the four initial tests gives an excellent correlation for the test series (Figure 3 ).

Overall material, total organic material, and elemental halances for the 105-hour test is contained in Tables 11, 12, and 13, respectively. Closure near 100 percent for the overall and total organic balances indicates a high degree of accuracy for the test data. Excellent carbon and hydrugen balance closures were obtained. The sulfur balance closure was high but is considered acceptable because of the smal.1 total amount of sulfur present in the entire materials system. Because of the problems in accurately measuring less than 1. wt of nitrogen content of the oils ('Table 14) it was not possible to achieve the proper nit rogen balance. In addition, the ammonia in the product gas was not measured.

Product gas yields and compositions for the 1.05-hour test are presented in Tables 9 and 15 , respectively. The weight percentage of total organics produced as gas for the entire 1.05 -hour test, $13.2 \%$ is in close agreement with the percentage produced during the equivalent 24-hour test (12.1\%). The methane and higher hydrocarbon concentrations were also similar indicating that the same degree of cracking had occurred. A comparison of the gas yields (Table 10) and composition of the gas (Table 15) for the separate phases of the 105-holr test. show that more cracking occurced during the final 72 hours than in the first 33 hours. This comparison suggests that the nptimum pyrolysis temperature may be closer to $600^{\circ} \mathrm{F}\left(316^{\circ} \mathrm{C}\right)$ than the predicted $650^{\circ} \mathrm{F}$ $\left(343^{\circ} \mathrm{C}\right)$.

Figure 3 suggests that the change in the oil yidid is very small in the pyrolysis temperature range of 600 to $700^{\circ} \mathrm{F}\left(316 \mathrm{to} 371^{\circ} \mathrm{O}\right)$. Also, the pyrolysis temperature is approximately $100^{\circ} \mathrm{F}\left(38^{\circ} \mathrm{C}\right)$ lower than that determined for the Asphalt $2 i d g e$ tar sand (Cha et a1. 1987). Consequently, we expect that the process cost for sunnyside tar sand will be lower than the cost for Asphalt Ridge tar sand. 


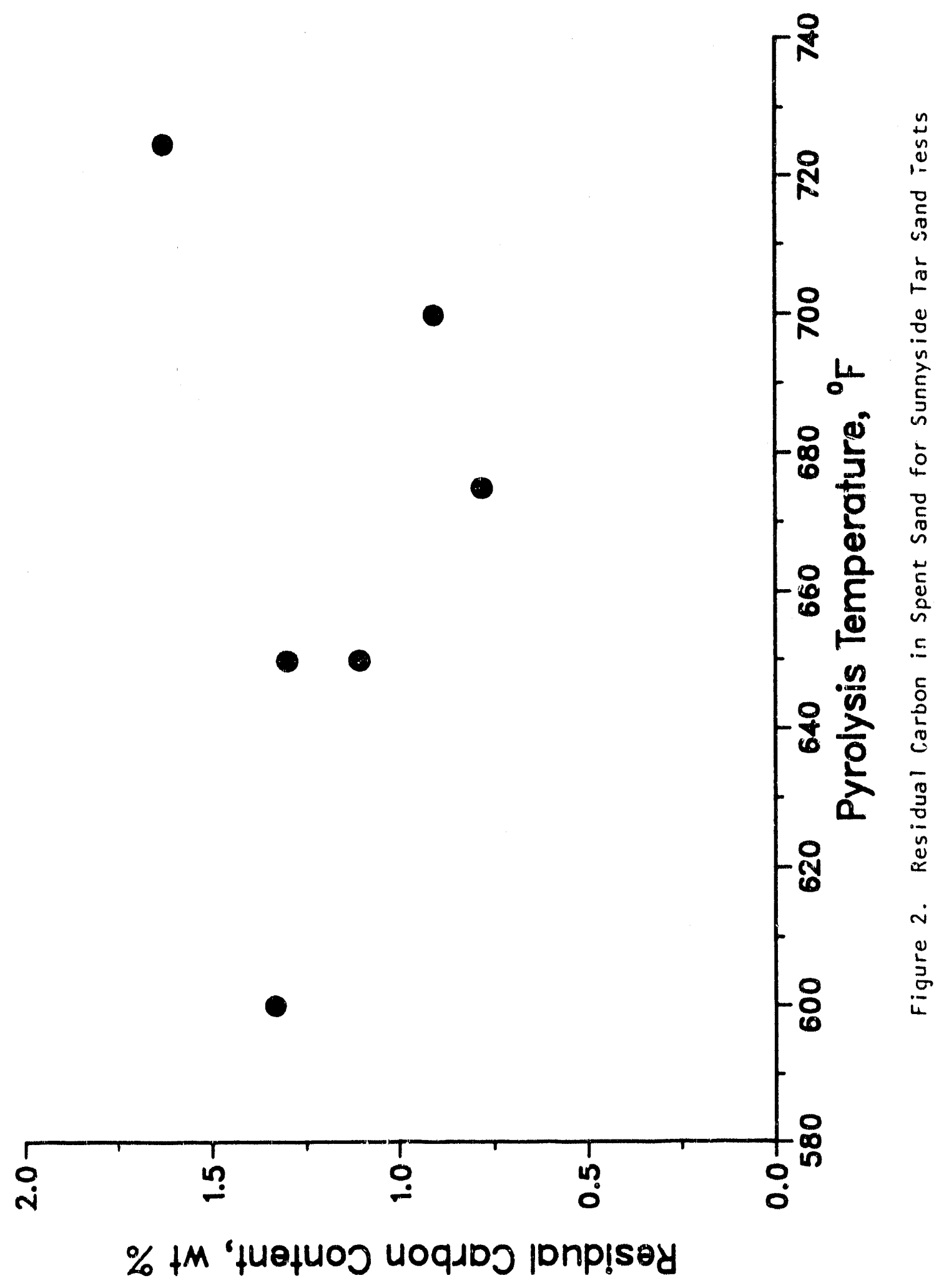




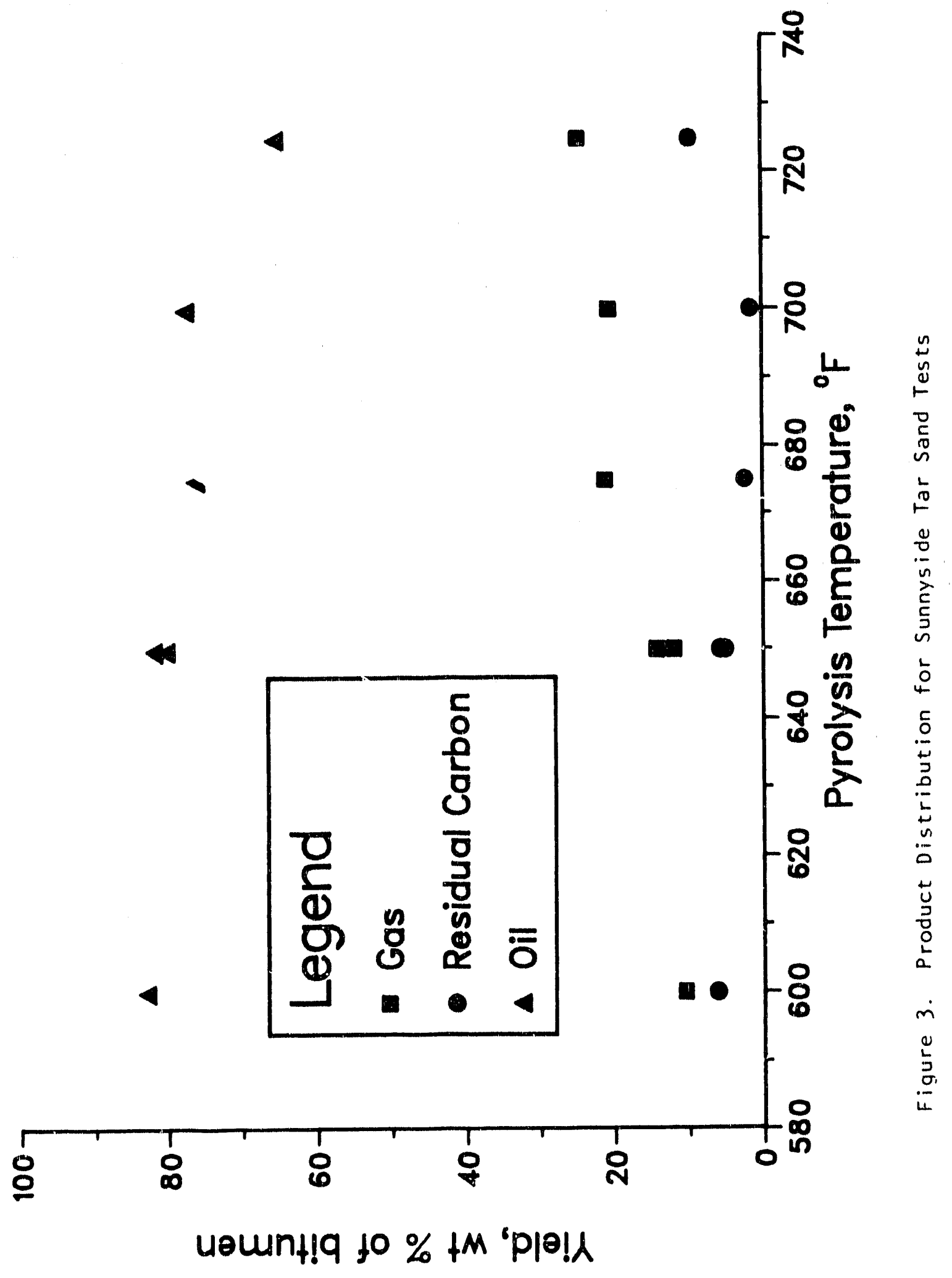


End Use Evaluation of Product oil

Hydrocarbon-type distrihutions were determined for three product oils from the two phases of the 10b-hour test. Because this test was conducted with tar sand product oil only and for a long period of time, we felt that the hydrocarbon-type distributions would olosely simulate commercicl results.

Total saturates and aromatics for the three product oils were determined on composite samples for the individual phases. The Ko2 and KO4 oils were evaluated to determine their potential market value as a fuel or fuel-blending stock (Tables 16 and 17). This evaluation divides the combined GC/MS data into distillate regions by correlating the boiling points of normal alkanes to their gas chromatographic retention times. Two distillate ranges were selected for this evaliation: IBP$350^{\circ} \mathrm{F}\left(\mathrm{IBP}-177^{\circ} \mathrm{C}\right)$, which represents a motor gasoline or blending stock, and $350-700^{\circ} \mathrm{F}\left(177-371^{\circ} \mathrm{C}\right)$, which represents aviation turbine fiel, highdensity aviation fuel feedstock, and diesel fuel.

Previous research un the ROPE ${ }^{(C)}$ process demonstrated that the product composition is directly related to the chemical composition of the feed resource. Resources that are more aliphatio in nat.ure form products that are aliphatic and are good sources of diesel fuel. Aromatic feeds produce aromatic products that are applicable for use as octane boosters for unleaded gasoline. The sunnyside tar sand is an aliphatic tar sand and should form products that are aliphatic. This is confirmed by the low specific gravity values of the products from sunnyside tar sand (Table 14).

Examination of the results in Table 16 shows that the hydrocarbontype distribution of the IBP $-350^{\circ} \mathrm{F}$ (IBP-177 $\mathrm{C}$ ) distillate fractions does not compare well with that of unleadsi gasoline. The major differences occur in the concentrations of the alkenes and alkylbenzenss. The products contain higher concentrations of alkenes and lower concentrations of alkylberzenes than does unleaded gasoline. This difference in the distributions will adversely affect the octane rating of the fuel. These products will have to be hyrlostahilized before they can be marketed, and this will hydrogenate the alkenes to produce additional a.lkanes. These will predominately be normal alkanes that do not have high octane values. Alkylbenzenes will have to he adred to these products to produce an unleaded gasoline.

The results in Table 17 suggest that the $350-700^{\circ} \mathrm{F}\left(177-371^{\circ} \mathrm{C}\right)$ distillate range of the products may have market value as a hlending stock for the p:roduction of diesel fuel. The products have high concentrations of alkanes and alkenes. The alkenes, upon hylrogenation, will form alkanes. The majority of the alkanes in the hydrotreated products will be normal alkanes and can be used as a hlemlinil stock to improve the cetane rating of diesel fuel. The products do not contain significant concentrations of dicyclic saturate or aromatic compounds and are not suited for the production of high-density aviation turbine fuels. 

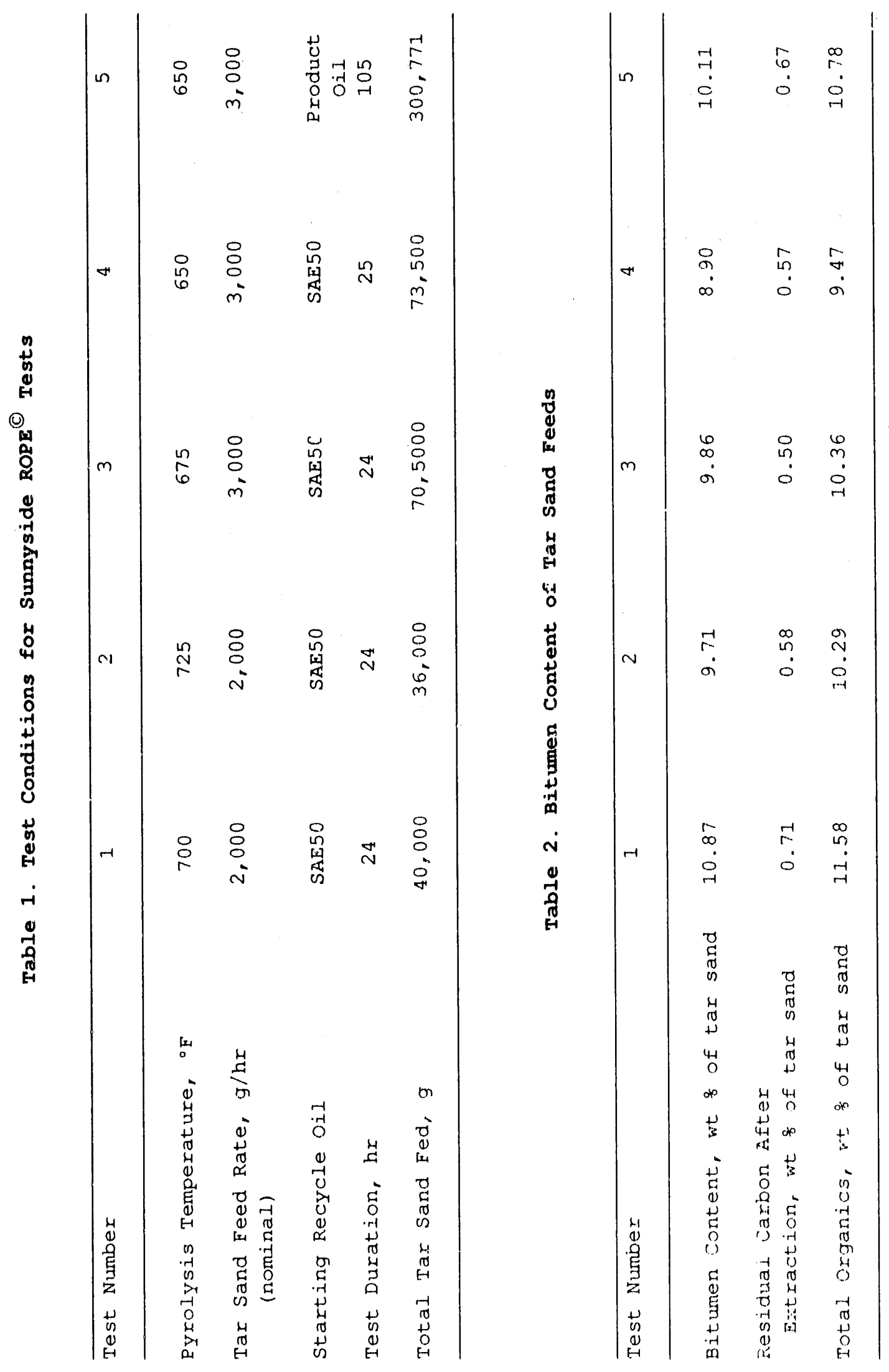


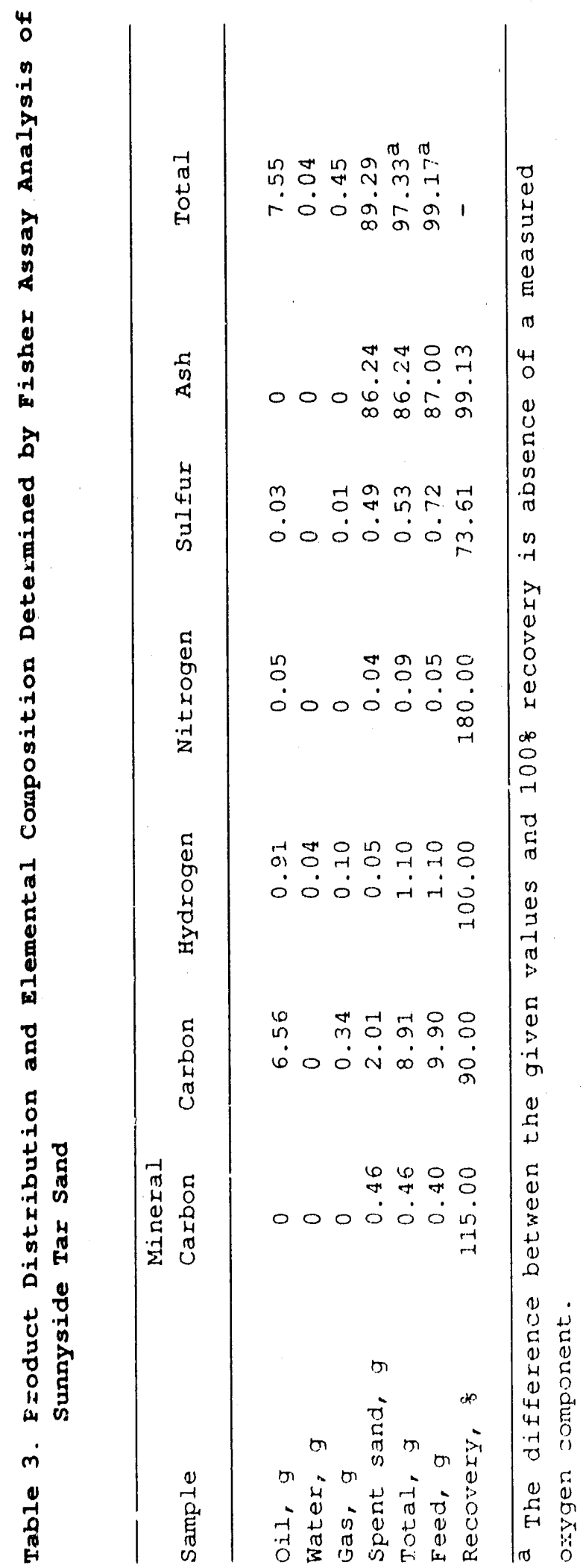


Table 4. Gas Composition Determination by Mass Balance Fisher Assay Analysis of Sunnyside Tar Sand

\begin{tabular}{lrr}
\hline Gas & Mole of Gas & Weight 8 of Gas \\
\hline & & \\
Hydrogen & 33.11 & 3.47 \\
Carbon monoxide & 2.93 & 4.19 \\
Carbon dioxide & 10.09 & 23.00 \\
Hydrogen sulfide & 1.33 & 2.12 \\
Carbonyl sulfide & 0 & 0 \\
Methane & 30.57 & 24.83 \\
Ethylene & 2.49 & 3.54 \\
Ethane & 7.84 & 7.93 \\
Propylene & 3.59 & 9.49 \\
Fropane & 4.26 & 1.08 \\
Isobutane & 0.74 & 5.00 \\
n-Butylene & 1.77 & 3.71 \\
n-Butane & 1.28 & 100.00 \\
Total & 100.00 &
\end{tabular}


Table 5. Properties of Sunnyside Bitumen

\begin{tabular}{|c|c|c|}
\hline Carbor, wt of & 86.3 & \\
\hline Hydrogen, wt $z$ & 11.7 & \\
\hline Nitrogen, wt 8 & 0.87 & \\
\hline Sulfur, wt $q$ & 0.46 & \\
\hline Oxygen (by difference) wt $q$ & 0.67 & \\
\hline H:C Ratio & 1.62 & \\
\hline Molecular Weight & 680 & \\
\hline Specific Gravity $060^{\circ} \mathrm{F}, \mathrm{g} / \mathrm{cm}^{3}$ & 0.997 & \\
\hline Viscosity, $\mathrm{QP}$ & & \\
\hline (a) $100^{\circ} \mathrm{F}$ & $1.6 \times 10^{8}$ & \\
\hline @ $140^{\circ} \mathrm{F}$ & $1.4 . \approx 10^{7}$ & \\
\hline Q195 ${ }^{\circ} \mathrm{F}$ & $1.6 \times 10^{5}$ & \\
\hline Distillation Data, wt 8 & & \\
\hline $\mathrm{IBR}-400^{\circ} \mathrm{E}$ & 0 & \\
\hline $400-500{ }^{\circ} \mathrm{F}$ & 0.5 & \\
\hline $500-600{ }^{\circ} \mathrm{F}$ & 2.1 & \\
\hline $600-700^{\circ} \mathrm{F}$ & 4.2 & \\
\hline $700-800{ }^{\circ} \mathrm{F}$ & 6.5 & \\
\hline $800-900{ }^{\circ} \mathrm{F}$ & 9.7 & · \\
\hline $900-1000{ }^{\circ} \mathrm{F}$ & 8.2 & \\
\hline$>1000^{\circ} \mathrm{F}$ & 68.8 & \\
\hline
\end{tabular}


Table 6. Overall Material Balances for the 24-Hour Tests

\begin{tabular}{|c|c|c|c|c|}
\hline Test Number: & 1 & 2 & 3 & 4 \\
\hline \multicolumn{5}{|l|}{ IN } \\
\hline Tax Sand, $g$ & 40,000 & 36,000 & 70,500 & 73,500 \\
\hline Starting Oil, g & 14,975 & 15,025 & 15,060 & 15,795 \\
\hline Total In, $g$ & 54,975 & 51,025 & 85,560 & $89,2.95$ \\
\hline \multicolumn{5}{|l|}{ OUT } \\
\hline Spent Sand, $g$ & 32,420 & 31,363 & 61,412 & 72,401 \\
\hline Jight Oi.l, g & 6,582 & 7,375 & 9,321 & 8,027 \\
\hline Heavy Oil, g & 13,182 & 9,452 & 10,664 & 12,743 \\
\hline Product Gas, g & 901 & 865 & $1,4 \%$ & 793 \\
\hline Total Out, $g$ & 53,085 & 49,055 & 82,867 & 93,964 \\
\hline \& Closure & 96.6 & 96.1 & 96.9 & 105.2 \\
\hline
\end{tabular}

* rotal in for four tests $=280,855 \mathrm{~g}$ Total out for four tests $=278,971 \mathrm{~g}$ \& closure $=99.3$ 
Tal) 7. Calculated Product Yields for the 24-Hour Tests

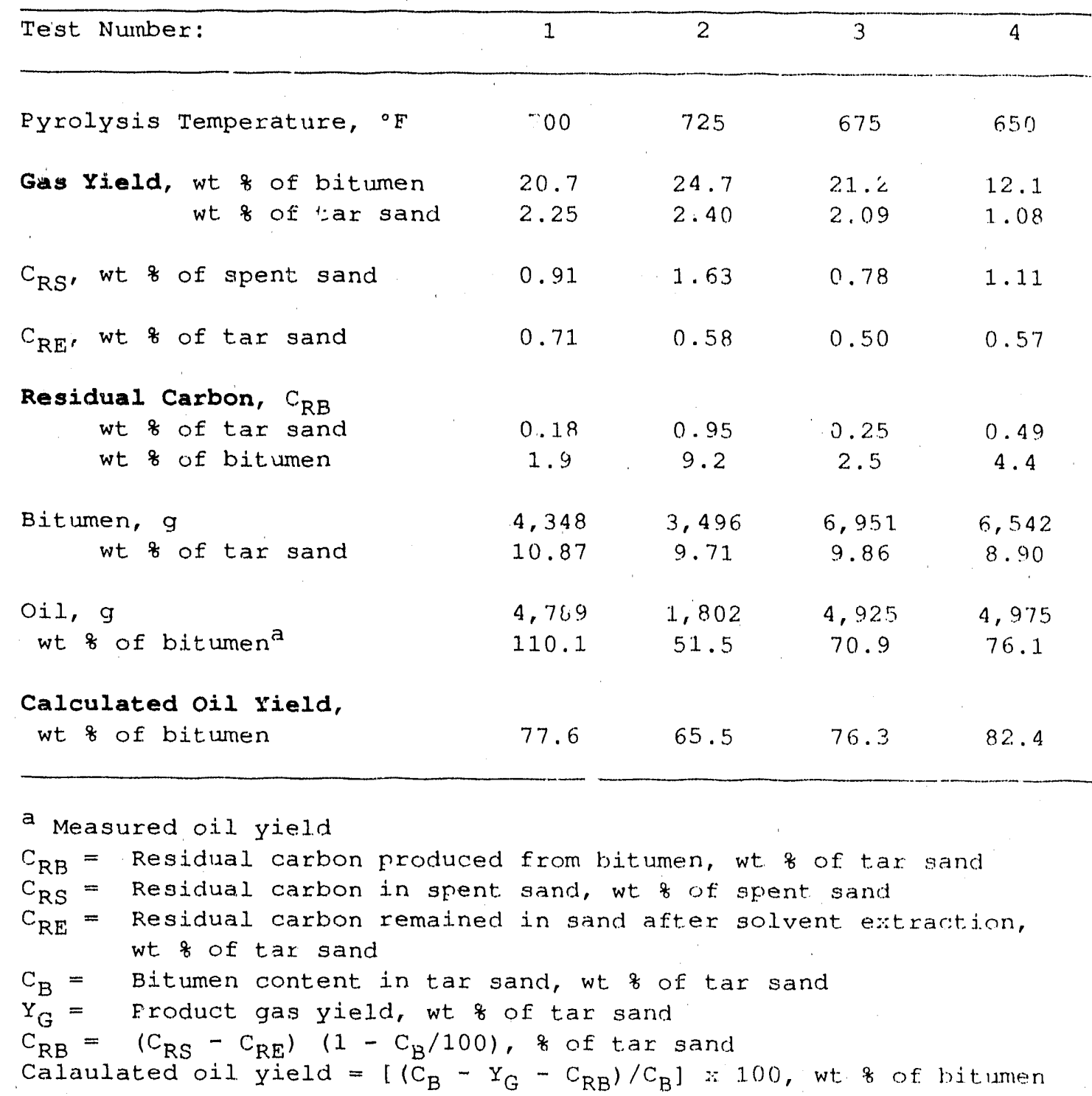


Table 8. Composition of Product Gas for the 24-Hour T sts, volume percent on dry basis

\begin{tabular}{|c|c|c|c|c|c|}
\hline Test Number: & & 4 & 3 & 1. & 2. \\
\hline \multicolumn{6}{|l|}{ Pyrolysis } \\
\hline Temperature, & ${ }^{\circ} \mathrm{F}$ & 650 & 675 & 700 & 725 \\
\hline $\mathrm{H}_{2}$ & & 28.00 & 19.65 & 21.20 & 14.86 \\
\hline $\mathrm{CO}$ & & 1.16 & 0.8 & 0.89 & 0.51 \\
\hline $\mathrm{CO}_{2}$ & & 10.61 & 7.50 & 6.60 & 4.52 \\
\hline $\mathrm{CH}_{4}$ & & 17.85 & 17.23 & 16.64 & 19.16 \\
\hline $\mathrm{C}_{2} \mathrm{H}_{6}$ & & 8.15 & 8.70 & 8.86 & 10.20 \\
\hline $\mathrm{C}_{2} \mathrm{H}_{4}$ & & 5.38 & 6.18 & 5.7 .1 & 8.07 \\
\hline $\mathrm{C}_{3} \mathrm{H}_{8}$ & & 5.41 & 6.35 & 5.93 & 6.86 \\
\hline $\mathrm{C}_{3} \mathrm{H}_{6}$ & & 7.72 & 8.97 & 8.07 & 10.42 \\
\hline $\mathrm{C}_{4} \mathrm{~s}$ & & 9.37 & 15.64 & 14.50 & 13.84 \\
\hline $\mathrm{C}_{5} \mathrm{~s}$ & & 6.33 & 8.91 & 11.60 & 11.58 \\
\hline $\mathrm{H}_{2} \mathrm{~S}$ & & 0.02 & 0 & 0 & 0 \\
\hline
\end{tabular}

Table 9. Measure Product Yields for the 105-Hour Test, weight percent of bitumen

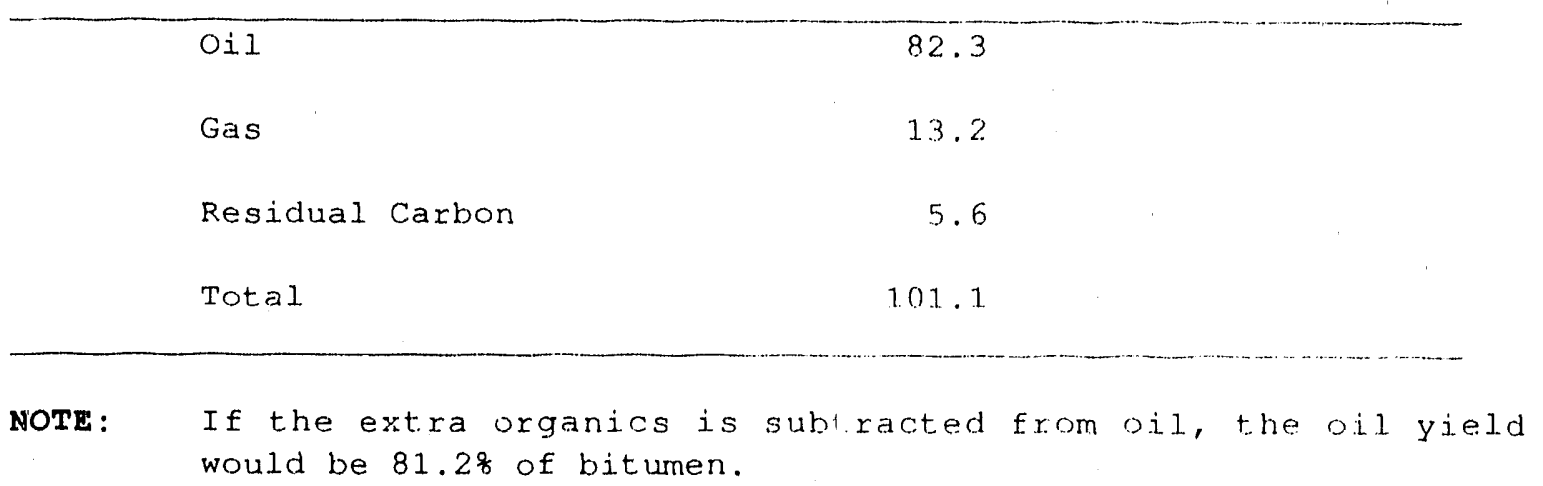


Table 10. Calculated Oil Yield for the 105-Hour Test, weight percent of bitumen

\begin{tabular}{|c|c|c|c|c|}
\hline . & F.A. & $\begin{array}{l}\text { Initial } \\
\text { 33 hr }\end{array}$ & $\begin{array}{l}\text { Final } \\
72 \text { hr }\end{array}$ & Dverall \\
\hline Pyrolysis Temp., ${ }^{\circ} \mathrm{F}$ & 932 & 600 & 650 & \\
\hline Gas & 4.7 & 10.6 & 1.4 .4 & 13.2 \\
\hline Residual Carbon & 29.8 & 6.3 & 5.2 & 5.6 \\
\hline Oj 1 & 65.5 & 83.1 & 80.4 & 81.2 \\
\hline Oil Yield, $=124$ 学 of F.A. & & & & \\
\hline
\end{tabular}

$\overline{F . A .}=$ Fisher Assay

Table 11. overall Material Balance for the 105-Hour Test

\section{IN}

Tar sand, $g$

product $0.11, \mathrm{~g}$

Total In, $\mathrm{g}$

OUT

Spent. Sand, $g$

light Oil (KO2), $g$

Light Oil (KO3), $\mathrm{g}$

Light Oil (KO4), $g$

Heavy O1i, $g$

Product Gas, $g$

product water, or

Total Out, g

\& Closure
300,771

23.789

324,560

268,306

21,718

56

13,869

13,196

4,022

1,882

$32.3,049$

99.5 
Table 12. Total Or janic Balance for the 105-Hour Test

IN

Total Organics in Tar sand, $g$

starting Oil, g

Total, g

OUT

Oil, g

Gas, $g$

Residual Carbon, g

Total, g

\& Closure
32,240

23,789

56,029

48,839

4,022

3,512

56,373

99.7

Table 13. Wilemental Balances for the 105-Hour Test

\begin{tabular}{|c|c|c|c|c|c|}
\hline & & Carbon & Hydrogen & Nitrogen & Sulfur \\
\hline \multicolumn{6}{|c|}{ IN } \\
\hline & Tar Sand, $g$ & 28,072 & 3,559 & 265 & 140 \\
\hline & Starting Oil, g & 20,554 & 3,093 & 24 & -95 \\
\hline & Total, $g$ & 48,626 & 6,652 & 289 & 2.35 \\
\hline \multicolumn{6}{|c|}{ OUT } \\
\hline & Spent Sand, g & 3,511 & - & - & - \\
\hline & Oil, g & $42,1.52$ & 5,903 & 154 & 186 \\
\hline & Gas, $g$ & 2,700 & 653 & - & 1.03 \\
\hline & Total, $g$ & 48,363 & 6,556 & 154 & 289 \\
\hline 8 & Closure & 99.5 & 98.6 & 53.3 & 123.0 \\
\hline
\end{tabular}




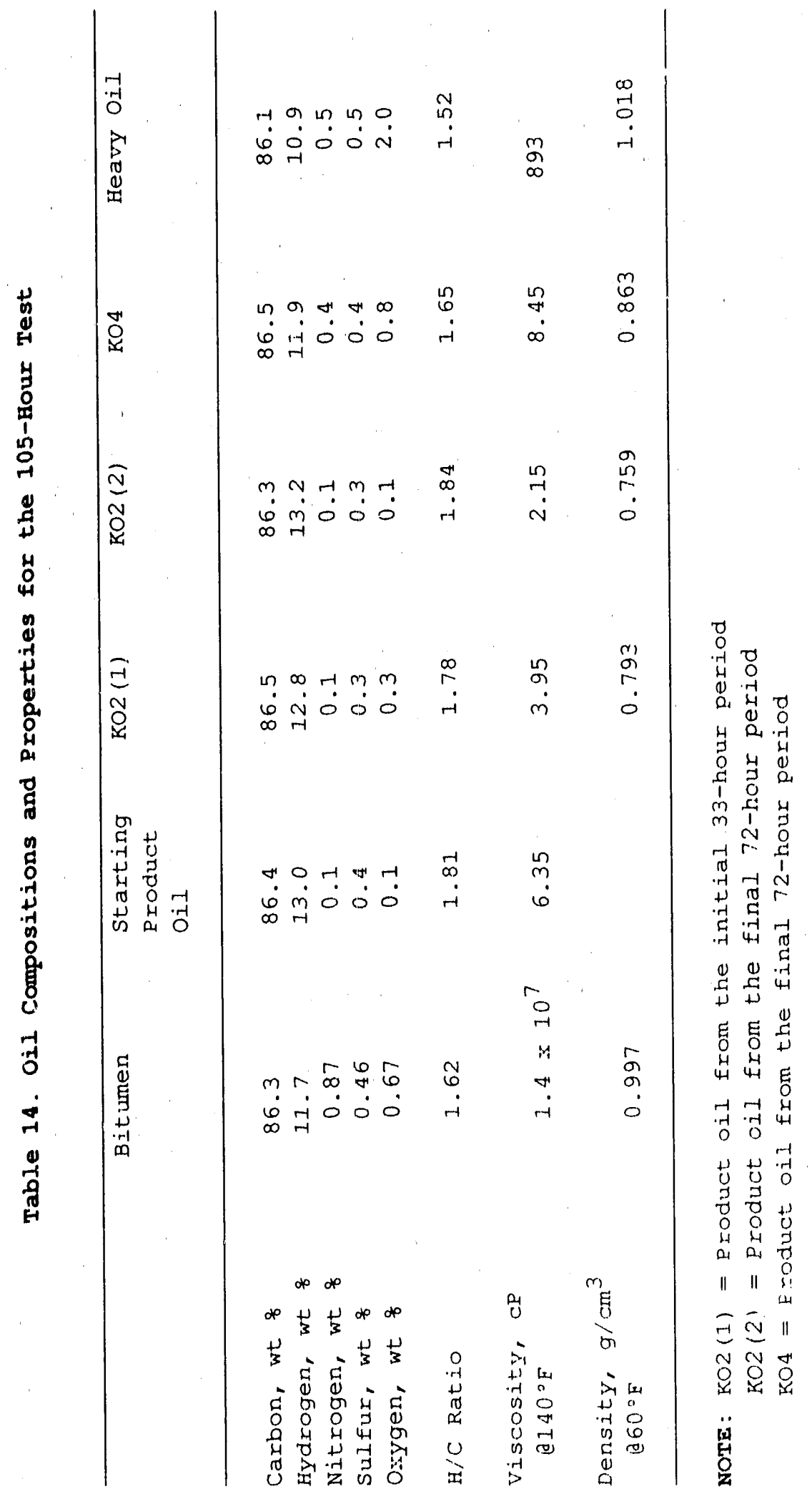


Table 15. Composition of Product Gas for the 105-Hour Test, volume percent on dry basis

\begin{tabular}{|c|c|c|c|}
\hline Component & $\begin{array}{c}\text { Fisher Assay } \\
\text { Gas }\end{array}$ & $\begin{array}{c}\text { Initial } 33 \text { hr } \\
\text { (Pyrolysis Temp. } \\
600^{\circ} \mathrm{F} \text { ) }\end{array}$ & $\begin{array}{c}\text { Final } 72 \text { hr } \\
\text { (Pyrolysis Temp. } \\
650^{\circ} \mathrm{F} \text { ) }\end{array}$ \\
\hline $\mathrm{H}_{2}$ & 33.23 & 26.24 & 28.12 \\
\hline $\mathrm{CO}$ & 2.94 & 2.68 & 1.61 \\
\hline $\mathrm{CO}_{2}$ & 10.13 & 15.43 & 9.41 \\
\hline $\mathrm{CH}_{4}$ & 30.68 & 20.78 & 22.04 \\
\hline $\mathrm{C}_{2} \mathrm{H}_{6}$ & 7.87 & 7.44 & 7.50 \\
\hline $\mathrm{C}_{2} \mathrm{H}_{4}$ & 2.50 & 3.99 & 4.01 \\
\hline $\mathrm{C}_{3} \mathrm{H}_{8}$ & 4.28 & 2.83 & 5.24 \\
\hline $\mathrm{C}_{3} \mathrm{H}_{6}$ & 3.60 & 5.71 & 5.34 \\
\hline $\mathrm{C}_{4}{ }^{\prime} \mathrm{s}$ & 3.80 & 9.44 & 11.39 \\
\hline $\mathrm{C}_{5}{ }^{\prime} \mathrm{s}$ & - & 4.15 & 3.29 \\
\hline $\mathrm{H}_{2} \mathrm{~S}$ & 1.33 & 2.31 & 2.05 \\
\hline
\end{tabular}


Table 16. Crmparison of Hydrocarbon-Group Types Identified in the IBP$350^{\circ}$ Distillate Fraction from the 105-Hour Test Product Oils with Unleaded Gasoline

\begin{tabular}{|c|c|c|c|c|}
\hline \multirow{2}{*}{ Hydrocarbon Type } & \multirow{2}{*}{$\begin{array}{l}\text { Unleaded } \\
\text { Gasoline }\end{array}$} & \multirow{2}{*}{ Phase 1 } & \multicolumn{2}{|c|}{ Phase 2} \\
\hline & & & $\mathrm{KO} 2$ & $\mathrm{KO4}$ \\
\hline \multicolumn{5}{|l|}{ Saturate Hydrocarbons, wt \& } \\
\hline A.lkanes & 24.1 & 21.8 & 25.1 & 24.8 \\
\hline Monocyclic alkanes & 24.7 & 19.7 & 20.4 & 21.8 \\
\hline Alkenes & -- & 36.2 & 35.7 & 36.3 \\
\hline Dicyclic alkanes & 0.0 & 0.8 & 0.3 & 0.2 \\
\hline Total & 48.3 & 78.5 & 81.5 & 83.1 \\
\hline \multicolumn{5}{|l|}{ Aromatic Hydrocarbons, wt 8} \\
\hline Alkylbenzenes & 41.9 & 20.8 & 18.3 & 16.7 \\
\hline Indanes/Tetralins & 6.6 & 0.7 & 0.3 & 0.4 \\
\hline Napthalenes & 2.7 & 0.0 & 0.0 & 0.0 \\
\hline Fluorenes & -- & 0.0 & 0.0 & 0.0 \\
\hline Anthracene/Phenanthrene & -- & 0.0 & 0.0 & 0.0 \\
\hline Total & 51.2 & 21.5 & 18.6 & 17.1 \\
\hline Wt of sample & -- & 27.4 & 31.8 & 16.9 \\
\hline
\end{tabular}

Note: All values are relative wt 8 


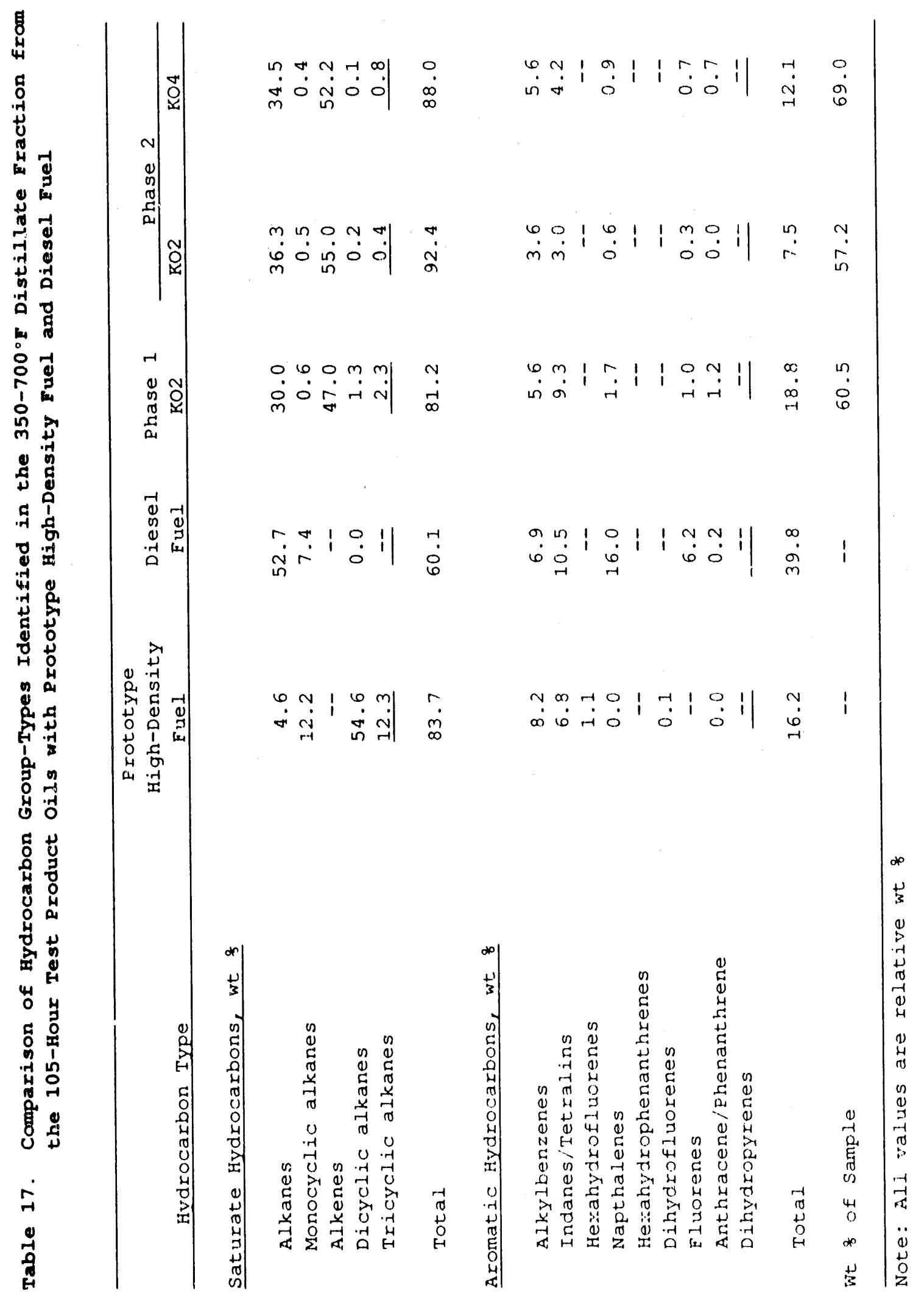




\section{CONCLUSIONS AND RECOMMENDATIONS}

The following conclusions can be drawn from the sunnyside tar sand 2-inch SPR tests:

- Tar sand can be processed using the ROPE process without any major operational difficulty.

- Oil yields greater than Fischer assay were obtained when the Sunnyside tar sand was pyrolyzed in the presence of recycled oil at 600 to $700^{\circ} \mathrm{F}\left(316\right.$ to $\left.371^{\circ} \mathrm{C}\right)$. An oil yield greater than 80 wt was obtained from the 105-hour test.

- The pyrolysis temperature of sunnyside tar sand in the presence of recycled oil was approximately $100^{\circ} \mathrm{F}\left(38^{\circ} \mathrm{C}\right)$ lower than the pyrolysis temperature of Asphalt Ridge tar sand. Also, the oil yield did not change significantly in the pyrolysis temperature of range 600 to $700^{\circ} \mathrm{F}\left(316\right.$ to $\left.371^{\circ} \mathrm{C}\right)$, which will provide a wide operating window.

- The gas yield was more than two times the gas yield for Asphalt Ridge tar sand, but the residual carbon remaining on the spent sand was less than one-half of that for the Asphalt Rirge tar sand.

- The gas yield increases with the increase in the pyrolysis temperature. However, the residual carbon on the spent sand decreases with temperature, reaches the minimum at ahout $675^{\circ} \mathrm{F}$ $\left(357^{\circ} \mathrm{C}\right)$, and increases with further increase in the pyrolysis temperature.

- The ratio of heavy oil to light product oil is strongly dependent upon the pyxolysis temperature and increases as the reaction temperature decreases.

- ROPE $^{(}$process product oils from sunnyside tar sand have market application as blending stocks for the production of diesel fuels, but they are not suited for the production of unleaded gasoline or high-density aviation turbine fuels.

We recommend that additional SPR tests be conducted with tar sand from AMOCO's actual site area and product oil. from AMOCO's processing of Sunnyside tar sand as initial recycle oil. One test should he a 24-hour 2-inch SPR tests at the pyrolysis temperature designater by AMOCC for varification of operational parameters. If the parmeters aj, ef with those from prior tests, then a 6-inch SPR test should be conducted for a minimum of 5 days to provide sufficient product oils for refining studies. These two tests will provide additional data for the economic evaluation and scale-up of the process. 


\section{ACKNOWLEDGMENTS}

The authors express their sincere appreciation to the I. S. Department of Energy (cooperative agreement DE-FC21-86MC11076) and the AMOCO Corporation for their joint funding of this work. Many people at the Western Research Institute have contributed to this program, and the althors sincerely thank all these dedicated people for their effort. Also, the authors would like to express their appreciation to Dr. Bob Iumpkin, Mr. Gene Tampa, and Mr. Ralph Avellanet for their strong support and encouragement during this investigation. 


\section{REFERENCES}

Cha, C.Y., F.D. Guffey, and T.J. Romanowski, 1987, sar Salyd Pyrolysis with Product Oil Recycling--Progress Report. Laramie, Wy, DUE Report DOE/MC/11076-2642.

Cha, C.Y., I.J. Fahy, and F.D. Guffey, 1988, Asphalt Ridge Tar Sand Recovery Using the ROPE (C) Process. Laramie, WY, DOE Report $\mathrm{DOE} / \mathrm{MC} / 11076-2659$.

Vaughn, P., C.Y. Cha, and F.D. Guffey, 1990, RopE (C) Frocessing of a California Tar Sand in a Two-Inch Screw Reactor. Laramie, WY, DOE report in progress. 

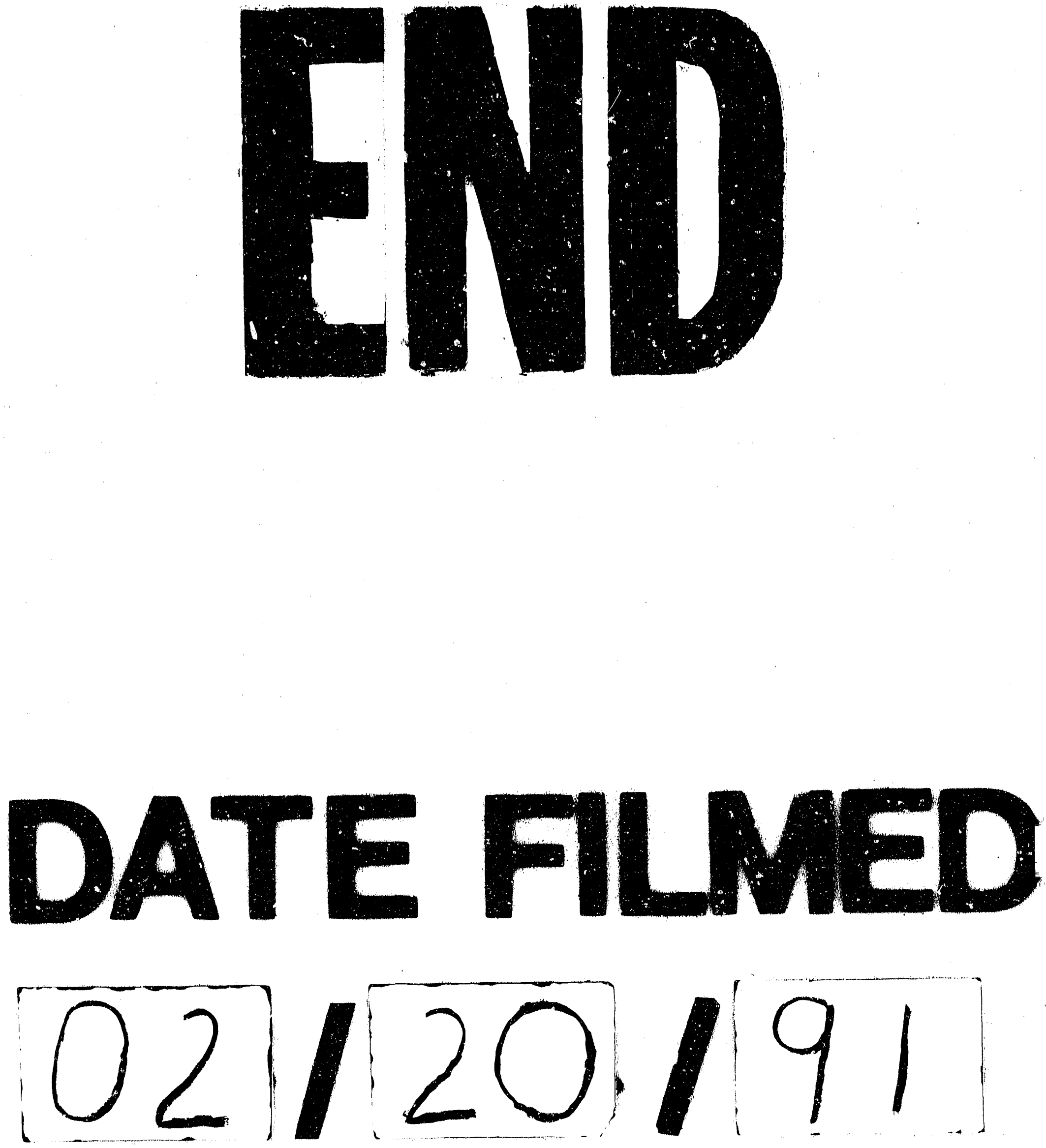
